\title{
The Relevance of Prior Learning in Teacher Education Admissions Processes
}

\author{
Mark Hirschkorn, Alan Sears, Elizabeth Sloat, University of New Brunswick \\ Theodore Michael Christou, Queen’s University \\ Paula Kristmanson, University of New Brunswick \\ Lynn Lemisko, University of Saskatchewan
}

\begin{abstract}
In this paper, we argue that teacher education admissions processes would benefit from attending more to prospective teacher candidates' cognitive frames. We begin with the introduction of a three-stage heuristic for describing teacher education. We then review the literature about constructivist notions of prior learning and teacher education program admissions processes. These processes, we argue, fail to adequately account for candidates' preconceptions about teaching and learning, which affect their beliefs and understanding. Virtually none of the admissions processes we examined explicitly attempts to map the cognitive frames of applicants to uncover the structure of their ideas about teaching and learning. Teacher education institutions might best concentrate upon candidates' cognitive frames within two core areas: subject area content knowledge and pedagogical knowledge. These two areas have the greatest potential to influence candidates' future cognitive frameworks, understandings, and points of reference.
\end{abstract}

Keywords: teacher education admissions processes; identifying cognitive frames; subject area content knowledge; pedagogical knowledge

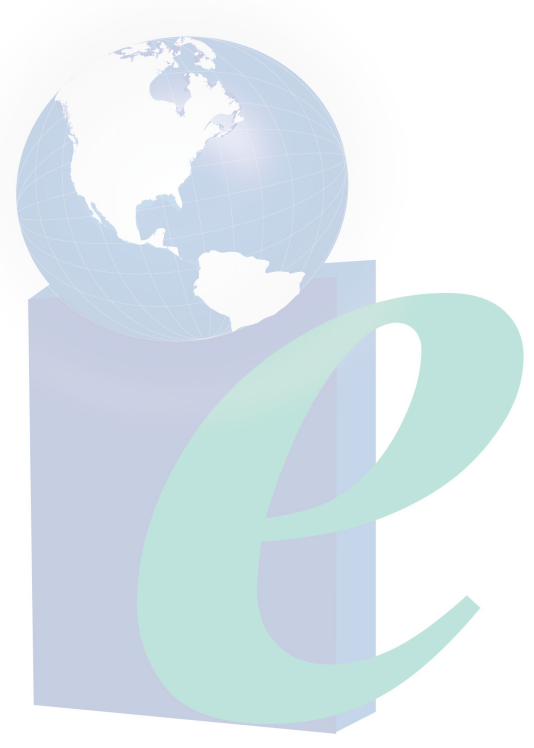




\section{The Relevance of Prior Learning in Teacher Education Admissions Processes}

What is the starting point in the education of a prospective teacher? Is it when candidates first walk through the doors of an education faculty, or perhaps the moment when they decide to become a teacher? One thing seems certain: Beginning teachers are not tabula rasa; they have preconceptions of teaching and learning that filter and shape the information and experiences they encounter in their formal teacher education. Teacher educators rely on teacher candidates' prior learning to shape and to individualize program delivery; but this paper inquires into what role candidates' prior learning might serve in admissions processes in advance of a teacher education program.

An emerging, although limited, scholarship has focused on institutional practices for admitting candidates to their teacher education programs (Kosnik, Brown, \& Beck, 2005; MillerLevy, Taylor, \& Hawke, 2014; Valli \& Johnson, 2007). The literature generally reflects the following two areas of interest: (a) the limitations of current admissions processes (e.g., Falkenberg, 2010) and (b) research on the effects of updated admissions models and new initiatives (e.g., Valli \& Johnson, 2007). We believe that teacher education programs, and ultimately schools, would benefit from attending more carefully to prospective teacher candidates' cognitive frames during the admissions process. We maintain that, in neglecting candidates' preconceptions about teaching and learning, one can easily overlook identifying candidates highly suited (and even unsuited) to any particular teacher education program and, more broadly, to professional teaching contexts. As researchers Miller-Levy, Taylor \& Hawke. (2014) contend, "High GPAs cannot predict responsive teaching strategies," though such data do “a reasonable job of screening for academics” (pp. 6-7).

To situate our argument, we begin by setting out a three-stage heuristic for describing the ongoing, evolutionary way that teachers begin and evolve in their professional learning, a process that begins long before entry to teacher education programs. We then review in brief constructivist notions of prior learning relative to teacher education program admissions processes. These processes, we maintain, fail to account adequately for candidates' preconceptions about teaching and learning, which affect their beliefs and understanding. We further contextualize our claim by arguing that teacher education institutions might best concentrate on candidates' cognitive frames within two core areas: subject area content knowledge and pedagogical knowledge. These two areas have the greatest potential to influence candidates' future cognitive frameworks, understandings, and points of reference.

\section{Becoming a Teacher}

There are a growing number of teacher education agencies, such as those in the European Union, that situate teacher education as a multi-stage process. Recent policies from the European Commission Directorate-General for Education and Culture (2014) and Ireland's Report on The Continuum of Teacher Education (An Chomhairle Mhúinteoireachta/The Teaching Council, 2011) conceive of teacher development as a process occurring along a continuum that begins with initial teacher education and proceeds to "induction, early and continuing professional development and, indeed, late career support, with each stage merging seamlessly into the next and interconnecting in a dynamic way with each of the others" (An Chomhairle Mhúinteoireachta/The Teaching Council, 2011, p. 8). This conceptualization aptly reflects a sequencing of developmental, evolutionary stages in which educators hone their professional 
knowledge, skills, and abilities. A growing number of teacher education programs are striving to achieve a level of seamless and dynamic learning by offering post-program initiatives aimed at supporting teachers during their first few years as teaching professionals (e.g., Kitchen, Cherubini, Smith, Goldblatt, \& Engemann, 2008).

We also conceptualize the evolution of becoming a teacher as a continuum occurring along three interconnected, developmental stages; however, in keeping with current theoretical perspectives (Dulude Lay et al., 2005; Falkenberg, 2010; Lortie, 1975; Richardson, 2003; Russell, 2009), we maintain that the evolutionary process begins long before entry to formal teacher education programs. Our three-stage model, therefore, includes (a) prior learning, which encompasses all of the learning, influences and experiences that occur prior to entry into a professional teacher education program; (b) the professional teacher education program learning itself; and (c) in-service professional learning, which entails all of the ongoing in-service teaching and professional development educators experience as members of the teaching profession. In conceptualizing teacher education as a continuum that is inclusive of teacher candidates' experiences prior to formal teacher education, we contend that models that exclude candidates' prior knowledge are insufficient. Further, we maintain that teacher education program admissions committees would be well served to "begin at the beginning" to ensure that "high-quality" program candidates are not overlooked in the admissions process. We discuss these issues more fully below by examining the relevance of prior learning in shaping teachers' dispositions and understandings about what it means to teach, and to learn.

\section{Prior Learning and Constructivist Theory}

Our argument for uncovering preservice teachers' embedded understandings and their reexperiencing of school is situated within contemporary constructivist theoretical frameworks of prior learning that have evolved from influential socio-cognitive conflict theorists (Dewey, 1933; Piaget, 1985; Vygotsky, 1978). Though social constructionist theories of learning are an equally significant though more recent influence (Lave \& Wenger, 1991), it was initially the cognitive and psychological literature that motivated education's shift from behaviouristic tabula rasa and empty vessel conceptions of learners to positioning knowledge as cumulative, evolutionary, and actively acquired phenomena. There is a well-established body of research demonstrating the ways in which beginning teachers' background knowledge and experiences significantly influence their conceptions of teaching and learning during their teacher education program studies and throughout their professional practice (e.g., Dulude Lay et al., 2005; Falkenberg, 2010; Lortie, 1975; Richardson, 2003; Russell, 2009). At the same time, however, there is a remarkable lack of research on how these prior understandings are used in the design and application of teacher education admissions processes (Tenore, Dunn, Laughter, \& Milner, 2010). We consider here, then, how that prior knowledge might be used to inform program candidate selection toward ensuring the best potential educators are chosen for our education systems. Taken from this vantage, we believe it is possible to create contexts for determining applicants' potential and willingness to think and to reflect critically, and to assume the teaching profession's central, constructivist practices and ways of knowing.

Much of the literature in this area explores the ways and means by which prior knowledge and epistemological beliefs can be used effectively to enhance the teacher education program learning experience. Lave and Wenger (1991) demonstrate that early, embedded, and entrenched cognitive frames fit with the philosophical tenets of constructivism, which define 
knowledge as co-created, socially situated, and context dependent. Central to constructivism is the understanding that prior knowledge matters to teaching and learning (Sears, 2009; Sloat et al., 2014). People come to any learning situation with a set of cognitive structures that filter and shape new information in powerful ways. As such, the process of becoming a teacher does not simply begin at entry to teacher education degree study. Through their own experiences as school and university students, beginning teachers have observed thousands of hours of teaching such that they have already acquired powerful and deeply embedded beliefs and dispositions about teaching and learning (Clark, 1988; Munby \& Russell, 1994). Lortie (1975) called this learning process the "apprenticeship of observation” (p. 62) to describe students' engagement in a wide array of classroom learning experiences that coalesce to perpetuate and reinforce an historical, well developed, and comfortably familiar perception of knowing how to teach.

Gardner (2006a) calls these influential cognitive structures “mental representations” and argues they underlie the fact that "individuals do not just react to or perform in the world; they possess minds, and these minds contain images, schemes, pictures, frames, languages, ideas, and the like” (p. 76). Research demonstrates that learners bring mental representations with them to learning situations, and that they use existing schemata to filter and shape new learning (Sears, 2009). These mental representations, or cognitive frameworks, are often incomplete, "naïve" (Byrnes \& Torney-Purta, 1995), or “simply wrong” (Gardner 2006b, p. 54). The deeply embedded beliefs about teaching acquired during the apprenticeship of observation are formed based primarily on the public, performance-related aspects of teaching and as such, initial cognitive teaching and learning frames are incomplete (Clark, 1988; Lortie, 1975). Though beginning teachers may have observed teachers and teaching in action, they do not necessarily have any tangible knowledge of the planning and activities that occur prior to the teaching "performance" they observe, and nor do they have any of the ideological and theoretical frameworks motivating teachers and the teaching they see in action. Beginning teachers have yet to become fully aware of all that is required and occurs in preparation for actual teaching.

Research on prior knowledge consistently shows that cognitive schemata are both persistent and resistant to change (Russell, 2009). When presented with information that does not fit existing structures, learners often distort or discard it completely rather than doing the difficult work necessary to restructure their frameworks. Candidates' conceptions of teaching and learning may complicate future learning and challenge their ability to change their cognitive frames. "Minds," Gardner (2006b) argues, "of course, are hard to change” (p. 1). If Gardner is correct, it may be most prudent for teacher education institutions to select candidates with the most potential to see teaching and learning in ways consistent with institutional conceptions of teaching and learning that are grounded in constructivist principles and ideals (e.g., DeLuca, 2012). This is particularly pressing when taking into consideration that formal teacher education programs are relatively short, at least in most jurisdictions (Sloat et al., 2014).

\section{Admissions Models and Accounting for Prior Learning}

As DeLuca (2012) asserts, “Admission policy plays a dominant role in the systematic selection of teacher candidates and serves as the primary gatekeeping structure for entry into the teaching profession in jurisdictions where teacher education is a university-based program of study" (p. 8). Multiple factors including lack of success in teacher education programs, high attrition rates in the early years of teaching, low student test scores, and persistent reports of poor teaching have led teacher educators in North America and Europe to examine their admissions policies 
and criteria for vetting program applicants (Brown, Brown, \& Brown, 2008; Casey \& Childs, 2007; Haberman, 2010; Turner \& Turner, 2000; Valli \& Johnson, 2007). While particular concerns may vary across jurisdictions, the basic empirical question is the same: "What initial qualities in applicants make it more likely for those admitted into a program to be successful in it relative to the desirable outcomes?” (Falkenberg, 2010, p. 2).

In response to these concerns, teacher education institutions have developed an array of admissions assessment criteria along with a plethora of mechanisms for determining the degree to which applicants meet those criteria (see, for example, Thomson et al, 2011). In addition to admissions processes described in the literature, we examined the publicly available admissions information at 12 initial teacher education (ITE) programs in Atlantic Canada (Hirschkorn, Ireland, \& Sears, 2014). The admissions procedures indicate that program administrators recognize key ways in which teacher formation begins long before admission to an initial teacher education program based on the request for information on indicators such as prior experience working with children and youth, prior teaching experience, and a rationale for why the applicant wants to be a teacher. These indicators do not, however, delve into the preconceived perceptions and knowledge constructs potential educators hold, and instead seek to identify candidates who are, or have the potential to be, academic experts, caring counsellors, skilled practitioners, and effective and collaborative colleagues. This knowledge is sought in admissions packages through a range of mechanisms, primarily academic credentials, personal statements of intent, and references from colleagues and academics.

While basic selection criteria are similar across contexts, added approaches to assessing applicants range from what we term minimal to maximal (see Figure 1). Those we considered to be minimal rely exclusively on written packages consisting of transcripts, references, and various statements or essays about becoming a teacher; maximal approaches augment written materials with performance assessments such as interviews and sample lessons as well as standardized tests and pre-admission experiential courses. The institutions in which we work, for example, take a minimal approach to assessing applicants via written application packages alone. These contain a fairly standard set of documents including university transcripts of previous degrees, a short statement outlining why the applicant wants to be a teacher, at least three letters of reference, and a record of previous experience working with children and young people.

The University of Jyväskylä, in Finland, moves further along the continuum toward a maximal approach by relying on a two-stage admissions process aimed at identifying potential candidates who possess the qualities and characteristics best suited for a demanding teaching career (Valli \& Johnson, 2007). Initially, at Stage 1, applicants are selected based on information provided in a written application package that addresses their prior academic studies and teaching-related experience. The selection process is then refined at Stage 2 with potential program candidates required to complete an "entrance examination" including a "demonstration lesson, interview, and group task” (Valli \& Johnson, 2007, p. 495). Demonstration lessons are unique because they require candidates to develop a curriculum-based, 10-15 minute lesson plan that they are then evaluated on in a classroom setting by trained observers.

The Faculty of Education at the University of Lethbridge in Alberta, Canada, embraces a maximal approach insofar as requiring applicants to take a full course as part of their university work prior to their application. The course includes both university seminars and school placements: 
[The course] has four purposes: to explore contemporary education, to help each student to assess the personal suitability of teaching as a career, to assist the Faculty of Education, in partnership with the teaching profession, to evaluate students' potential for teaching and for admission to the B.Ed. program, and to assist the student in beginning to make the transition from student to professional educator. (Butt, Grigg, \& McConahy, 2010, p. 2)

Following course completion, students meet individually with an instructor to discuss their suitability for the teaching profession and, in addition to a grade, receive an assessment ranging from Highly Recommended to Not Recommended. This particular pre-admission model has the potential to focus intentionally on discerning students' ways of knowing and thinking about teaching and learning, and the degree to which the views they hold align with effective constructivist ideology.

Table 1: Minimal-to-Maximal Continuum of Program Admission Procedures

\begin{tabular}{|c|c|c|}
\hline Minimal 4 & & $\rightarrow$ Maximal \\
\hline $\begin{array}{l}\text { Written Application } \\
\text { Package Including: } \\
\text { - University Transcripts } \\
\text { - Sample Essay and/or } \\
\text { Statement of Intent } \\
\text { - Letters of Reference }\end{array}$ & $\begin{array}{l}\text { Written Application } \\
\text { Package Including: } \\
\text { - University Transcripts } \\
\text { - Sample Essay and/or } \\
\text { Statement of Intent } \\
\text { - Letters of Reference }\end{array}$ & $\begin{array}{l}\text { Written Application } \\
\text { Package Including: } \\
\text { - University Transcripts } \\
\text { - Sample Essay and/or } \\
\text { Statement of Intent } \\
\text { - Letters of Reference }\end{array}$ \\
\hline & $\begin{array}{l}\text { Performance Assessments } \\
\text { such as: } \\
\text { - Interviews } \\
\text { - Sample Lessons } \\
\text { - Individual/Group } \\
\text { Activities } \\
\text { - Assessment Centres }\end{array}$ & $\begin{array}{l}\text { Performance Assessments } \\
\text { such as: } \\
\text { - Interviews } \\
\text { - Sample Lessons } \\
\text { - Individual/Group } \\
\text { Activities } \\
\text { - Assessment Centres }\end{array}$ \\
\hline & $\begin{array}{l}\text { Standardized Tests such as } \\
\text { PRAXIS Series, common in } \\
\text { the U.S. }\end{array}$ & $\begin{array}{l}\text { Standardized Tests such as } \\
\text { PRAXIS Series, common in } \\
\text { the U.S. }\end{array}$ \\
\hline & & $\begin{array}{l}\text { Pre-Admission, Experiential } \\
\text { Course Containing: } \\
\text { - Practicum } \\
\text { - Exposure to Educational } \\
\text { Pedagogy, Thinkers, \& } \\
\text { Theories } \\
\text { - Concluding Interview } \\
\text { with Recommendation } \\
\text { for Admissions }\end{array}$ \\
\hline
\end{tabular}


As Casey and Childs (2007) point out, whatever the approach teacher education programs use, there are enduring problems in the area of assessing the suitability of candidates for program admission. First, "the relationship of admissions criteria to the knowledge, skills, and attitudes beginning teachers need and to the preparation provided by the programs are rarely made explicit” (p. 2). Haberman (2010) concurs with Casey and Childs, and similarly argues that not only do faculties and teacher educators in general lack both definition and agreement on the knowledge, learning theories, and ideologies teaching candidates should possess, but also that the latter, ideologies of effective teaching, are impossible to teach to others anyway (p. 142). Second, what counts as successful teaching is difficult to define absolutely. Success could be correlated with significant accomplishments as a teacher, but accomplishments are measured differently in diverse jurisdictions and there is a paucity of longitudinal scholarship that follows graduates from different contexts into their careers. Consequently, Casey and Childs (2007) argue, "Most studies of teacher education program admission criteria have used success in the program itself as indicators of the probability of future success” (p. 10). Here again, in critiquing the predominant selection process for teacher education program admission, Haberman (2010) maintains that simply "practicing the behaviours of effective teachers... would still not constitute adequate teacher preparation”(p. 141). Behaviours, he continues, can only be effective when program candidates demonstrate through their actions that they possess a specific ideology about the nature of students, teaching, and learning, while also recognizing societal influences on curriculum.

Virtually none of the admissions processes we examined explicitly attempts to map the cognitive frames of applicants to uncover the structure of their ideas about teaching and learning. Even in more complex approaches, emphasis is placed on more tangible elements such as a candidate's level of comfort working with children and peers, or technical aspects of lesson delivery such as organization of material, pacing, and voice modulation. Candidates are sometimes asked about their conceptions of teachers and teaching, but this evidence seems to be treated anecdotally and not analysed systematically for what it might reveal about the cognitive schemata of applicants. This is particularly curious given the widespread consensus among academics in education internationally about the appropriateness of constructivist approaches to teaching and learning, including attention to prior knowledge (Brownlee, Purdue, \& BoultonLewis, 2001; Tanase \& Wang, 2010).

If, as we contend, teacher candidates come to programs with well-entrenched conceptions about what a teacher is, what it means to teach, and the nature of the subjects they plan to teach, and if these mental representations or cognitive frames are highly difficult to change, it follows that selection processes should make some attempt at assessing existing frames and give preference to applicants who are more consistent with contemporary approaches to teaching and learning. Teacher education programs are of limited duration and, as Russell (2009) argues, their relatively short length barely scratches the surface of prospective teachers' conceptions of teaching derived over a lifetime of learning in different venues. Selecting candidates most disposed to thinking about and reflecting on teaching in ways consistent with contemporary views has the potential to enhance successful transition into the profession.

We posit that there are three possible reasons for the marginal attention that is paid to the cognitive frames of teacher education program applicants. First, there is little consensus about what good teaching is and how it should be conceived. Second, cognitive frames are extremely difficult to assess. Third, there is the threat of a lack of diversity within the teaching profession 
when institutions only accept candidates who conform to a narrowly defined set of criteria. We do not believe these obstacles are insurmountable and, consequently, we turn now to offering suggestions for how they might be addressed.

\section{Areas of Consensus}

First, we maintain that there is a fair degree of consensus about the nature of effective teaching that program admissions committees might use for screening potential applicants. Casey and Childs (2007) argue: “Although researchers have focused on different aspects of what it means to be a good teacher, four qualities related to teachers' needs appear repeatedly in the literature: content knowledge, pedagogical knowledge, pedagogical skills, and attitudes” (p. 4). There is a fair degree of agreement amongst teacher educators and faculties about how these qualities are defined. An examination of literature and curricula from democratic countries around the world reveals significant consensus about content, pedagogy, and the nature of learners (see, for example, Hughes, Print, \& Sears, 2008; Hughes \& Sears, 2010). Major national reports on teacher education in Canada, Ireland, and the U.S. argue that good teachers require a solid grounding in both pedagogy and subject-matter content knowledge and, in particular, a welldeveloped sense of how these two areas come together as pedagogical content knowledge in teaching and learning. (e.g., An Chomhairle Mhúinteoireachta/The Teaching Council, 2011; Crocker \& Dibbon, 2008; Darling-Hammond \& Bransford, 2005; Shulman, 1986; Waldron et al., 2009). Below, in Figure 2, we delineate core elements of constructivist views of "effective teaching" by setting these elements against traditional conceptions of teaching and learning. Though our list is far from exhaustive, it does capture the premise that there is a consensual understanding of what effective teaching is and looks like.

Table 2: Constructivist Consensus on Effective Teaching

\section{$\underline{\text { Traditional Conception } \longrightarrow \text { Constructivist Conception }}$}

Knowledge/Understanding: Fixed and universal conceptions of knowledge and understanding with a focus on "right" answers

Curriculum Relevancy: Fragmented, lower-order thinking, teacher-centred curriculum that students tend to regard as irrelevant

Students: Based on a deficit 'empty vessel' model where students are merely passive, compliant knowledge recipients
Knowledge/Understanding: Fluid, contextual, and cultural focus on diverse perspectives that involve disciplinary concepts and processes

Curriculum Relevancy: Integrated, interdisciplinary, student-centred curriculum that students tend to regard as connected to their own interests, talents, experiences, and the real world

Students: Based on an active, engaged, hands-on, performance-based model Where students actively create knowledge and understanding to become agents of change 
Teaching and Learning: Prevailing approaches are authoritarian, rote, textbook driven, and didactic for delivering a singular perspective on curricular content and learning outcomes

\section{Society, Institutions, and Disciplinary} Communities: Regarded as Static, stable, enduring and "right," with students expected to accept and adapt to traditional values and norms
Teaching and Learning: Prevailing approaches are authoritative and constructivist emphasizing attention to prior learning, culture, multiple perspectives, dissonance and variation in learning outcomes

\section{Society, Institutions, and Disciplinary Communities: Regarded as non-static, changing, context-dependent, and always in need of re-examination and reformation with students expected to understand and participate in institutional reshaping}

\section{Content Knowledge Frames}

In addition to considerable consensus about the nature of effective teaching, there is growing accord about the understandings of specific subject matter that teachers should foster. Figure 2 indicates that a constructivist approach to subject matter construes knowledge as constructed, fluid, and contextual rather than fixed and universal. Increasingly, policy and curricula around the world are mandating that schools foster students' understanding, ways of knowing, and facility with the key concepts, activities, and communicative competencies germane to each of the academic disciplines they study. Disciplinary inquiry, then, teaches learners to think like and to use the knowledge held by members of the science community, the history community, the literary arts community, and so on. Howe (2009), for example, argues that contemporary science curricula call for students to develop an understanding of the nature of science as a discipline. This is important because it helps "students develop their understanding so they will become critical consumers of the very scientific knowledge that increasingly impacts their daily lives” (p. 397). He contends that teaching the history of science is the key way to achieve this as it fosters an understanding that "there are historical, cultural, and social influences on the practice of science.” Howe (2009) suggests that students study critical episodes in the history of science engaging with questions such as: "How was the scientist's work influenced by the culture in which he/she operated? What ramifications may his/her conclusions have on sociological or political policy? Did any issues of ethics or values come into play with the historical episode?” (p. 397).

Similarly, but with respect to mathematics, Jankvist (2009) contends that students should come to understand mathematics as a socially constructed system with a long and complex evolutionary history, to see it as:

A discipline that has undergone an evolution and is not something that has arisen out of thin air; that human beings have taken part in its evolution; that mathematics has evolved through many different cultures throughout its history and that these cultures have had an influence on the shaping of mathematics and vice-versa; or that the evolution is driven by internal and external forces. (p. 239) 
Likewise, history educators around the world emphasize a disciplinary approach to teaching this subject. There is some variation on precise elements of what is most often called "historical thinking" across jurisdictions but the core components are the same (see, for example, Barton \& Levstik, 2004; Seixas \& Morton, 2013; Stearns, Seixas, \& Wineburg, 2000). Levesque (2008) states, "Disciplines such as history have their own modes of inquiry, networks of concepts and principles, theoretical frameworks, symbolic systems, vocabularies, and modes of self-regulation"(p. 7). The purpose of school history is to introduce students to these disciplinary understandings and processes. Levesque asserts that, for this to happen, teachers need sophisticated understanding of the discipline.

Currently, teacher candidates' subject matter knowledge is assessed almost exclusively based on the number of university courses they have in a particular discipline. The one exception to this is the U.S. where, in addition to post-secondary academic history, applicants to many teacher education programs are required to take a standardized test, parts of which assess basic content knowledge (Brown et al., 2008). Both of these approaches are inadequate for assessing teacher candidates' understandings of and facility with important disciplinary concepts and processes. What is more, transcript analysis alone poses a far greater risk of fostering professional conformity according to a narrow set of criteria compared with admissions procedures that would seek to uncover and explicate existing cognitive frameworks. Candidates might address a variety of ways to define and relate their learning to disciplinary understanding and to pedagogical content knowledge. These approaches, which we describe in detail below, may broaden institutional conceptions about candidates understanding, prior learning, and cognitive frames. Course names and grades listed on transcripts, independently of any further data, reveal only limited information about what candidates may know about education's instructional disciplines.

Gardner (2006a) points out that "disciplines represent the most advanced ways to think about issues consequential to human beings. Yet from a disciplinary point of view, the ways in which most of us think about these issues are fundamentally flawed” (p. 138). Further, he notes that "both disciplinary content and disciplinary habits of mind may be deeply counterintuitive" (Gardner, 2006a, p. 138,). If disciplinary understanding is both fundamental to quality teaching and hard to acquire, perhaps teacher education institutions should select candidates that demonstrate how they are predisposed to thinking about their subject areas in disciplinary terms.

We argue that the qualities described in Figure 2 apply generally across teaching areas. Further, we suggest that they can serve as descriptors of quality teachers who regard learners as active builders of knowledge and understanding. A number of studies have used concept mapping as a means for describing how teachers think about their profession (see Seezink, Poell, \& Kirschner, 2009; Vincente, Bermejo, Blanco, \& Ruiz, 2008), and this technique can be used in admissions processes. In spite of years of emphasizing more constructivist and critical approaches to teaching in academic literature and teacher education programs, there is considerable evidence that fairly traditional, transmissive practices continue to dominate school classrooms (Goodlad, 1984; Minor, Onwuegbuzie, Witcher, \& James, 2002; Tyack \& Cubin, 1995). A considerable part of the resistance to change may be attributable to deeply held conceptions of teachers and teaching that are inconsistent with constructivist and critical approaches to teaching and learning. Selecting candidates for the profession who are disposed to thinking about education in constructivist or critical ways may help in the process of teacher 
identity formation, and has the potential to move more classrooms to constructivist ways of learning.

We note several caveats to contextualize the argument. Assessing the cognitive frames of teacher education candidates for compatibility with contemporary conceptions of subject matter, teaching, and learning is not tantamount to believing that all teacher candidates should think the same way. Prospective teacher candidates will inevitably have diverse experiences prior to those that a teacher education program engages them with and still be willing to challenge their own cognitive frames and conceptions of teaching and learning. The contention that assessing prospective teacher candidates' cognitive frames would unjustly narrow the range of individuals accepted into teaching fails on two counts. First, it implies that current practices do not already limit the range of candidates based on set characteristics including views about aspects of the educational enterprise. Second, a wide diversity of perspectives can exist within the two areas of consensus outlined.

Are current practices exclusionary? In Canada, for example, the Association of Canadian Deans of Education (ACDE) has signed an Accord on Initial Teacher Education (2005), which, amongst other matters, makes explicit a concern for social justice. The Accord states: "An effective initial teacher education program promotes diversity, inclusion, understanding, acceptance, and social responsibility in continuing dialogue with local, national, and global communities” (ACDE, 2005, p. 4). This statement, one of several of like spirit in the Accord, privileges a particular kind of candidate as appropriate to teacher education. It is difficult to believe that teacher candidates who question the positive nature of ethnic and cultural diversity in Canada in an application essay would be selected for admission to any teacher education program in the country. However, if we do not ask the question, then we cannot know what perceptions potential candidates hold. It is appropriate that the ACDE has set out some parameters for teacher education that include potential filters to help in the selection of appropriate candidates for the profession. Assessing teacher candidates' preconceptions of the teaching and learning process and the academic disciplines they intend to teach is equally appropriate, particularly when there is transparency regarding assessment criteria, and that these align with widely accepted conceptions of quality teaching and learning.

What is more, diversity of perspectives can exist even in areas of consensus. There is wide agreement, for example, that students should understand history as discipline but as a discipline that is contested (e.g. Lee \& Ashby, 2000; Lévesque, 2008; Taylor, 2004; Wineburg, 2001). As an indicative example, recent debates regarding the nature of history as a discipline and its practice in universities, museums, historic sites, and schools have been termed the "history wars" (see, for example, Linenthal \& Engelhardt, 1996; Macintyre \& Clark, 2004; MacMillan, 2008; Taylor \& Guyver, 2012). To ask that prospective teacher candidates have an understanding of a discipline is not to require them to take a particular position on its nature and purpose; it is, rather, an expectation that they are involved in the ongoing discussion and debate regarding what constitutes that discipline. We argue that no one can understand, or seek to understand, a discipline without understanding it as a contested and socially constructed means of engaging with the world and with ourselves.

In his seminal work on communities of practice, Etienne Wenger (1998) argues that professional communities function best as sites of learning when there is the right degree of creative tension between reification and participation. Reification, or the setting out of explicit 
policies and procedures, is necessary because it gives shape and consistency to professional practice, but an emphasis on it alone can squelch growth and contribute to the stagnation of practice. Wenger argues that members of a community of practice must be able to participate in shaping and reshaping policies and practices if the community is to be a dynamic site of professional learning and growth. Constructivist approaches to teaching and learning have reached the status of reification across most Western education systems. Consequently, they form a basis for judging both conceptions of teaching and teaching practice. We recognize and affirm the fact that participants in the profession will participate in challenging and reshaping these conceptions and practices over time.

\section{Suggested Modifications to Teacher Education Admission Models}

Any particular model used by teacher education institutions to assess applications will inevitably require compromise. Factors such as cost of delivering program, time of year, availability of candidates and faculty to serve as readers, and number of applicants all shape the assessment practices of an institution. It would, for instance, be difficult for a large institution that admits many hundreds of applicants each year to use a model requiring a significant amount of time devoted to the consideration of each application. There are relatively simple steps teacher education institutions can do to bring to the fore candidates' cognitive frames for assessing their potential fit with the program. Here, we consider three components relative to the core, or minimal, program application materials common to many institutions' admissions packages: (a) sample essays or statements of intent; (b) university transcripts; and, (c) reference letters. Further, we set out example modifications that can be applied to teacher education application materials.

For prospective candidates to complete their admissions materials, however, they will require contextual information about the foundational cognitive frames institutions themselves value. Teacher education program faculty, therefore, need to identify and delineate clearly for applicants and application review committees their own cognitive frames in three interconnected areas: (a) the cognitive frames underpinning their various program stream offerings; (b) their disciplinary and curricular content knowledge frames; and, (c) their pedagogical orientations and frames. Most institutions offer a range of program stream offerings such as those of school systems from early childhood through the primary, elementary, middle, and high school years, and many offer an array of adult education program streams as well. What, then, are the underlying philosophies, orientations, and perceptions about teaching and learning in, for example, the early years and primary grades that a faculty values? This question, while it may initially seem relatively straight forward, is further complicated by the particular concentrations that many teacher education programs include in their offerings. These include educational foundations, counselling, special education, social justice, second language education, technological education, and First Nations education. These concentrations may have their own foundational conceptions that fit within the programs’ larger frames and beliefs.

The picture is further complicated at the intermediate and secondary levels given the distinct cognitive frames underlying the various curriculum disciplines such as mathematics, science, language arts, history, and so on. Each discipline is grounded in a particular set of philosophical, ideological, and conceptual understandings, both as a discipline in and of itself, and in terms of how that discipline should be framed for teaching and learning. The complete picture, both at the macro and micro levels should be made known to potential program 
candidates. Similarly, applicants and application review committees need to know the institutional conceptions about issues particularly relevant to the early, primary, and elementary school grades, such as beliefs about children's cognitive, affective, and psychomotor development; approaches to language, literacy, reading, and writing development; and whether the institution adheres to a theme-based, integrated curriculum approach. At the same time, an institution's pedagogical frames for all programs need to be clearly articulated so applicants can address these elements in their application materials. There must, therefore, be a clear articulation of, for instance, whether an institution places emphasis on teacher-centered versus student-centred approaches to teaching and learning; whether, and how, program emphasis is placed on active versus passive learning; whether, and how, program emphasis is given to testand print-based or performance-based assessments; whether institutions favor a time-based versus an outcome-based curriculum organization orientation, and so on.

Table 3: Example Modifications to Teacher Education Application Materials

\begin{tabular}{|c|c|}
\hline $\begin{array}{l}\text { Core } \\
\text { Application } \\
\text { Components }\end{array}$ & $\begin{array}{l}\text { Application Modifications that Facilitate Disciplinary, Content, and } \\
\text { Pedagogical Cognitive Frames Articulation }\end{array}$ \\
\hline $\begin{array}{l}\text { Essay or } \\
\text { Statement of } \\
\text { Intent }\end{array}$ & $\begin{array}{l}\text { - Explain their own conceptions about teaching and learning in their chosen } \\
\text { grades and, where relevant, their chosen disciplines; } \\
\text { - Describe the content knowledge learning they value; } \\
\text { - Recall critical learnings experienced as a student and explain both the } \\
\text { conditions surrounding that learning and why it was effective; } \\
\text { - Outline relevant, applicable pedagogical understandings and orientations; } \\
\text { and/or } \\
\text { - Address the measures you would take as an educator to ensure the } \\
\text { learning needs and interests of First Nations, second language learners, or } \\
\text { special needs learners are met. }\end{array}$ \\
\hline $\begin{array}{l}\text { University } \\
\text { Transcripts }\end{array}$ & $\begin{array}{l}\text { - Explain in writing the choices that drove prior program degree and course } \\
\text { selections; } \\
\text { - Set out explanations for achievement levels; } \\
\text { - Describe what was learned from specific courses particularly relevant to } \\
\text { the education curriculum; } \\
\text { - Articulate overall how academic background prepares them for teaching; } \\
\text { and/or } \\
\text { - Describe the strengths and limitations of the pedagogical approaches you } \\
\text { experienced as a student and learner in your degree courses and program }\end{array}$ \\
\hline
\end{tabular}




\begin{tabular}{|l|l|}
\hline Letters of \\
Reference & $\begin{array}{l}\text { - Provide at least one academic reference in which the referee speaks } \\
\text { specifically to the applicant's disciplinary orientation and expertise; } \\
\text { and/or }\end{array}$ \\
$\begin{array}{l}\text { - Provide at least one workplace reference in which the referee speaks } \\
\text { specifically to the applicant's pedagogical knowledge, skills, and } \\
\text { orientation }\end{array}$ \\
\hline
\end{tabular}

An institution's clearly articulated ideological and conceptual orientations provide prospective candidates with foundational intelligence that can inform their application and make their cognitive frames more explicit. Applications are more focused rather than generic, since prospective candidates must address in their admissions materials the specific pedagogical, content, and age or grade-level streams to which they are applying. For instance, as Figure 3 above reflects, those applying to the secondary program, curriculum concentrations must be selected as teachable subjects, must explain their own conceptions about teaching and learning in their chosen grades and disciplines, and describe the content knowledge learning they value. Similarly, at least one referee could be asked to speak specifically to the applicant's disciplinary orientation and expertise, while another workplace colleague or administrator could be asked to speak to the candidate's pedagogical preferences. When written statements are combined with other application package materials such as degree transcript explanations and discipline-specific letters from qualified referees who can speak directly to candidates' subject-specific knowledge and skill, a more comprehensive conception of an applicant's cognitive frames can emerge.

We recommend three areas of the research literature for faculty and admissions committees to draw on to inform and support their work in assessing applicant's suitability for and fit in the program. First, they can draw on teacher education literature, which is rich with examples of assessing student and practicing teachers' conceptions of teaching and learning (i.e., Chen, Chan, Tang, \& Cheng, 2009; Minor et al., 2002). Second, they can consider research on students' disciplinary thinking in a range of fields, which facilitates their assessment of the degree to which applicants understand key concepts and processes related to particular disciplines (e.g., Gardner, 2006a). Third, they can engage with phenomenographic research, which seeks to map the ways in which people conceptualize important ideas (i.e. Carlsson, Fülöp, \& Marton, 2001; Marton, 1981; Richardson, 1999;) and which can be used to foster understanding how applicants and teacher educators conceptualize aspects of teaching, education, and professional practice. These three areas of research feature various interview techniques and activities designed to elicit conceptual understandings that can be adapted for use in admissions procedures.

\section{Conclusion}

As Casey and Childs (2011) aptly assert, “At a time when admission to initial teacher education programs is highly competitive, choices of admission criteria are particularly relevant” (p. 17). In this paper, we have argued that teacher education institutions may benefit from greater attention to candidates' prior learning and cognitive frames by understanding the tenets and principles underpinning a candidate's conceptions of learners and learning as well as of teachers and teaching. It is only by knowing potential candidates' embedded understandings that we can 
gauge whether the values, beliefs, and judgments influencing the methods and strategies they choose for organizing, delivering, and assessing students' learning hold proper merit. Cognitive frames affect teacher candidates' decision-making, thinking, and action in educational contexts and within disciplines; they are, largely, in place before the beginning of a teacher education program. It is incumbent on teacher education institutions to seek information regarding applicants’ cognitive frames, and to articulate their own more explicitly.

We recognize that by increasing the specificity of what institutions value in candidates and the ability of these institutions to determine what cognitive frameworks teacher candidates possess, they risk not admitting students who could become successful teachers over the course of a teacher education program. Nonetheless, we believe that knowing more about prospective teachers' underlying assumptions regarding teaching and learning is valuable. This knowledge, we argue, increases the likelihood that programs can develop understanding of these cognitive frameworks even as it increases the likelihood that candidates will flourish as professional teachers with beliefs and understandings that are more fully developed. However, a benefit of these suggested modifications to both application packages and screening activities is that they would provide an opportunity for faculty to discuss and to potentially reach consensus regarding the cognitive frames and disciplinary orientations they seek in their teacher candidates. This would permit teacher education programs to make these more explicit to present and potential candidates.

An increasing number of U.S. states require a pre-professional skills test (PPST) in order to be admitted to teacher education programs and a PRAXIS series at graduation (CochranSmith, Feinman-Nemser, McIntyre, \& Demers, 2008). These tests are not the only assessment devices used, although there are required minimum scores before being admitted to a teacher education program. Thus, the tacit agreement described above is seemingly not as sacrosanct as it once was (Goodwin \& Oyler, 2008). Even without questioning the validity of using tests to measure the potential of prospective teachers, such assessments undermine the flexibility of teacher education programs to admit students who are exemplary in categories other than their state-mandated test scores. In the end, we believe that teacher education admissions processes should seek to assess the cognitive frames of applicants, which they presently fail to do, in a systematic manner. By concentrating on applicants' frames with respect to disciplinary knowledge and pedagogical knowledge, they may best develop and influence candidates' belief systems, understanding, and philosophies of practice.

\section{References}

An Chomhairle Mhúinteoireachta/The Teaching Council. (2011). Policy on the Continuum of Teacher Education. Maynooth: An Chomhairle Mhúinteoireachta/The Teaching Council. Retrieved from http://www.teachingcouncil.ie/en/Publications/Teacher-Education/Policyon-the-Continuum-of-Teacher-Education.pdf.

Association of Canadian Deans of Education(ACDE). (2005). Accord on Initial Teacher Education. Retrieved from http://www.cssescee.ca/docs/acde/acde_teachereducationaccord_en.pdf.

Barton, K. C., \& Levstik, L. S. (2004). Teaching history for the common good. Mahwah, NJ: Lawrence Erlbaum. 
Brown, J. R., Brown, L. J., \& Brown, C. L. (2008). Signs, signs, everywhere there's signs . . . and the sign says": You got to have a PRAXIS II membership card to get inside. Teacher Education Quarterly, 35(1), 29-42.

Brownlee, J., Purdie, N., \& Boulton-Lewis, G. (2001). Changing epistemological beliefs in preservice teacher education students. Teaching in Higher Education, 6(2), 247-268.

Butt, R., Grigg, N., \& McConaghy, G. (2010). Predicting success in teacher education through a workplace learning selection process. Paper presented at the 2nd Paris International Conference on Education, Economy and Society, Paris, France.

Byrnes, J., \& Torney-Purta, J. (1995). Naive theories and decision making as part of higher order thinking in social studies. Theory and Research in Social Education, 23(3), 260-277.

Carlsson, M. A., Fülöp, M., \& Marton, F. (2001). Peeling the Onion: Student Teachers' Conceptions of Literary Understanding. Scandinavian Journal of Educational Research, 45(1), 5-18.

Casey, C. F., \& Childs, R. A. (2007). Teacher education program admission criteria and what beginning teachers need to know to be successful teachers. Canadian Journal of Educational Administration and Policy, 67, 1-24.

Casey, C., \& Childs, R. (2011). Teacher education admission criteria as measure of preparedness for teaching. Canadian Journal of Education, 34(2), 3-20.

Chen, M., Chan, K., Tang, S., \& Cheng, A. (2009). Pre-service teacher education students' epistemological beliefs and their conceptions of teaching. Teaching and Teacher Education, 25, 319-327.

Clark, C. (1988). Teacher preparation: Contributions of research on teacher thinking. Educational Researcher, 17(2), 5-12.

Cochran-Smith, M., Feiman-Nemser, S., McIntyre, D., \& Demers, K. (2008). Handbook of research on teacher education: Enduring questions in changing contexts (3rd ed.). New York, NY: Routledge/Taylor and Francis and the Association of Teacher Educators.

Crocker, R., \& Dibbon, D. (2008). Teacher education in Canada: A baseline study. Kelowna, $\mathrm{BC}$ : Society for the Advancement of Excellence in Education.

Darling-Hammond, L., \& Bransford, J. (Eds.). (2005). Preparing teachers for a changing world: What teachers should learn and be able to do. San Francisco, CA: Jossey-Bass.

DeLuca, C. (2012). Selecting Inclusive Teacher Candidates: Validity and Reliability Issues in Admission Policy and Practice. Teacher Education Quarterly, 39(4), 7-32.

Dewey, J. (1933). How we think. Buffalo, NY: Prometheus.

Dulude Lay, C., Pinnegar, S., Reed, M., Young Wheeler, E., \& Wilkes, C. (2005). The positioning of preservice teacher candidates entering teacher education. In J. Brophy \& S. Pinnegar (Eds.), Learning from research on teaching: Perspective, methodology, and representation (pp. 235-252). Netherlands: Elsevier. 
European Commission Directorate-General for Education and Culture (July 2014). Initial Teacher Education in Europe: An Overview of Policy Issues. ET2020 Working Group on Schools Policy 2014. Retrieved from http://ec.europa.eu/education/policy/strategicframework/expert-groups/documents/initial-teacher-education_en.pdf.

Falkenberg, T. (2010). Admission to teacher education programs: The problem and two approaches to addressing it. Canadian Journal of Educational Administration and Policy, 107, 1-35.

Gardner, H. (2006a). Changing minds: The art and science of changing our own and other people's minds. Boston, MA: Harvard Business School Press.

Gardner, H. (2006b). The development and education of the mind: The selected works of Howard Gardner. New York, NY: Routledge.

Goodlad, J. (1984). A place called school: Prospects for the future. New York, NY: McGrawHill.

Goodwin, A, \& Oyler, C. (2008). Teacher educators as gatekeepers: Deciding who is ready to teach. In M. Cochran-Smith, S. Feiman-Nemser, and D. J. McIntyre (Eds.), Handbook of research on teacher education: Enduring questions in changing contexts (pp. 468-489).

New York, NY: Routledge.

Haberman, M. (2010). How to make university-controlled teacher education and alternative certification programs accountable for the quality of teachers in schools serving children and youth in poverty. In V. Hill-Jackson \& C. Lewis (Eds.), Transforming teacher education (pp. 121-152). Sterling, VI: Stylus.

Howe, E. (2009). Henry David Thoreau, forest succession and the nature of science: A method for curriculum development. American Biology Teacher, 71(7), 397-404.

Hirschkorn, M., Ireland, K., \& Sears, A. (2014). Becoming teacher: Sites for development of Canadian teacher education. In L. Thomas, (Ed.), Disrupting teacher development: The role of teacher education (pp. 209-234). Retrieved from https://sites.google.com/site/cssecate/fall-working-conference.

Hughes, A., Print, M., \& Sears, A. (2010). Curriculum capacity and citizenship education: A comparative analysis. Compare, 40(3), 293-309.

Hughes, A., \& Sears, A. (2008). The struggle for citizenship education in Canada: The centre cannot hold. In J. Arthur, I. Davies, \& C. Hahn (Eds.), The Sage handbook of education for citizenship and democracy (pp. 124-138). London, UK: Sage.

Jankvist, U. (2009). A categorization of the "whys" and "hows" of using history in mathematics education. Educational Studies in Mathematics, 71(3), 235-261.

Kitchen, J., Cherubini, L., Smith, D., Goldblatt, P., \& Engemann, J., (2008). Learning from experience: Supporting beginning teachers and mentors (Ontario College of Teachers and Brock University Report). Retrieved from https://www.oct.ca//media/PDF/Learning\%20from\%20Experience\%20Book\%205\%20Research\%20Summary /EN/induction_booklet5_e.pdf. 
Kosnik, C., Brown, R., \& Beck, C. (2005) The preservice admissions process: What qualities do future teachers need and how can they be identified in applicants? The New Educator, 1(2), 101-123.

Lave, J., \& Wenger, E. (1991). Situated learning: Legitimate peripheral participation. New York: NY: Cambridge University Press.

Lee, P., \& Ashby, R. (2000). Progression in historical understanding Ages 7-14. In P. Stearns, P. Seixas, \& S. S. Wineburg (Eds.), Knowing, teaching, and learning history: National and international perspectives. New York: New York University Press.

Lévesque, S. (2008). Thinking historically: Educating students for the twenty-first century. Toronto, ON: University of Toronto Press.

Linenthal, E., \& Engelhardt, T. (Eds.). (1996). History wars: The Enola Gay and other battles for the American past. New York, NY: Metropolitan.

Lortie, D. (1975). Schoolteacher: A sociological study. Chicago, IL: University of Chicago Press.

Macintyre, S., \& Clark, A. (2004). The history wars. Melbourne, AU: Melbourne University Press.

MacMillan, M. (2008). The uses and abuses of history. Toronto, ON: Viking.

Marton, F. (1981). Phenomenography: Describing conceptions of the world around us. Instructional Science, 10, 177-200.

Miller-Levy, R., Taylor, D., \& Hawke, L. (2014). Maintaining the boundaries: Teacher preparation program admission criteria for screening quality candidates. Administrative Issues Journal: Education, Practice, and Research, 4(1), 40-50. doi: 10.5929/2014.4.1.8. Retrieved from http://www.swosu.edu/academics/aij/2014/v4i1/miller-taylor-hawke.pdf

Minor, L., Onwuegbuzie, A., Witcher, A., \& James, T. (2002). Preservice teachers' educational beliefs and their perceptions of characteristics of effective teachers. Journal of Educational Research, 96(2), 116-127.

Munby, H., \& Russell, T., (1994). The authority of experience in learning to teach: Messages from a physics methods class. Journal of Teacher Education, 45(2), 86-95.

Piaget, J. (1985). The equilibration of cognitive structures: The central problem of intellectual development. Chicago, IL: University of Chicago Press.

Richardson, J. (1999). The concepts and methods of phenomenographic research. Review of Educational Research, 69(1), 53-82.

Richardson, V. (2003). Preservice teachers’ beliefs. In J. Raths \& A. McAninch (Eds.), Teacher beliefs and teacher education. Advances in teacher education (pp. 1-22.). Greenwich, CT: Information Age. 
Russell, T. (2009, October). Is innovation in teacher education possible, and can self-study help? Paper presented at the Inspiration and Innovation in Teaching and Teacher Education (EDGE) Conference, St. John’s, NFLD, Canada.

Sears, A. (2009). Children's understandings of democratic participation: Lessons for civic education. In M. Print \& H. Milner (Eds.), Civic education and youth political participation (pp. 143-158). Rotterdam, NL: Sense.

Seezink, A., Poell, R., \& Kirschner, P. (2009). Teachers' individual action theories about competence-based education: The value of the cognitive apprenticeship model. Journal of Vocational Education and Training, 61(2), 203-215.

Seixas, P., \& Morton, T. (2013). The big six historical thinking concepts. Toronto, ON: Nelson.

Shulman, L. (1986). Those who understand: Knowledge growth in teaching. Educational Researcher, 15(4), 4-14.

Sloat, E., Sherman, A., Christou, T., Hirschkorn, M., Kristmanson, P., Lemisko, L., \& Sears, A. (2014). Restoring higher education's mission in teacher education: A global challenge from a Canadian perspective. In V. Ellis \& J. Orchard (Eds.), Learning teaching from experience: Multiple perspectives and international contexts (pp. 143-159). London, UK: Bloomsbury.

Stearns, P., Seixas, P., \& Wineburg, S. (Eds.). (2000). Knowing, teaching, and learning history: National and international perspectives. New York: New York University Press.

Tanase, M., \& Wang, J. (2010). Initial epistemological beliefs transformation in one teacher education classroom: Case study of four preservice teachers. Teaching and Teacher Education, 26, 1238-1248.

Taylor, T. (2004). Disputed territory: Some political contexts for the development of Australian historical consciousness. In P. Seixas (Ed.), Theorizing historical consciousness (pp. 217239). Toronto, ON: University of Toronto Press.

Taylor, T., \& Guyver, R. (Eds.). (2012). History wars and the classroom: Global perspectives. Charlotte, NC: Information Age.

Tenore, F., Dunn, A., Laughter, J., \& Milner, H. (2010). Teacher candidate selection, recruitment, and induction: A critical analysis with implications for transformation. In V. Hill-Jackson \& C. Lewis (Eds.), Transforming teacher education (pp. 93-118). Virginia: Stylus.

Thomson, D., Cummings, E., Ferguson, A., Moizumi, E., Sher, Y., Wang, X., Broad, K., \& Childs, R. (2011). A role for research in initial teacher education admissions: A case study from one Canadian university. Canadian Journal of Educational Administration and Policy, 121, 1-23.

Turner, S., \& Turner, T. (2000). Who succeeds? A case study of science graduates following postgraduate certificate in education (secondary) courses. European Journal of Teacher Education, 23(2), 159-174. 
Tyack, D., \& Cuban, L. (1995). Tinkering toward utopia: A century of public school reform. Cambridge, MA: Harvard University Press.

Valli, R., \& Johnson, P. (2007). Entrance examinations as gatekeepers. Scandinavian Journal of Educational Research, 51(5), 493-510.

Vincente, M., Bermejo, M., Blanco, L., \& Ruiz, C. (2008). The classroom practice of a prospective secondary biology teacher and his conceptions of the nature of science and of teaching and learning science. International Journal of Science and Mathematics Education, 6(1), 37-62.

Vygotsky, L. (1978). Mind in society. Cambridge, MA: MIT Press.

Waldron, F., Pike, S., Greenwood, R., Murphy, C. M., O'Connor, G., \& Dolan, A., (2009). Becoming a teacher: Primary student teachers as learners and teachers of history, geography and science: An all-Ireland study. Armagh: The Centre for Cross Boarder Studies.

Wenger, E. (1998). Communities of practice: Learning, meaning, and identity. Cambridge: Cambridge University Press.

Wineburg, S. (2001). Historical thinking and other unnatural acts: Charting the future of teaching the past. Philadelphia, PA: Temple University Press. 